\title{
SPIRITUALITAS PANDEMIK: TINJAUAN FENOMENOLOGI IBADAH DI RUMAH
}

\author{
Hasahatan Hutahaean ${ }^{1}$, Bonnarty Steven Silalahi ${ }^{2}$, Linda Zenita Simanjuntak ${ }^{3}$ \\ ${ }^{1}$ Sekolah Tinggi Teologi Sumatera Utara, ${ }^{2}$ Universitas Pelita Harapan Medan Kampus, \\ ${ }^{3}$ Sekolah Tinggi Teologi Arastamar Riau \\ Email: hasea2014@gmail.com
}

\begin{abstract}
This research departs from the facts in the reality that we faced since the determination of the COVID-19 pandemi in Indonesia. The churches convert every activity from the church into homes. This phenomenon brings researchers to the spirituality of the congregation during a pandemi with devotions at home. A qualitative approach with a methodological method is used to obtain teaching from these experiences on the spiritual side. With a sample of one hundred respondents from four Churches Congregation who held every devotion activities at home, they realized that the opportunity to understand God's sovereignty upon the whole world, and increasingly surrendered to Him (arround 94\%). The respondent composition is dominated by attending live streaming $(96 \%)$ while doing devotion at home with church printed-out services is $3 \%$. Several respondents found $2.6 \%$ sharing the Word by themself in the devotion session at home. By this research, there is hope for churches to take a serious look to the digital field by forming a digital commission/department or another designation with the task of serving the online services because advances in information technology become tools that cannot be ignored for the advancement of church services and developments. The pandemi did not pose a threat to the congregation to grow and rush on the spiritual side
\end{abstract}

Key Words: spirituality, phenomenology, pandemi, home devotions.

\begin{abstract}
ABSTRAK: Penelitian ini berangkat dari fakta di lapangan yang ada sejak penentuan pandemik korona jenis baru di Indonesia. Gereja-gereja mengalihkan ibadah di gereja menjadi di rumah-rumah. Fenomena ini membawa peneliti kepada sisi spiritualitas jemaat selama pandemik dengan ibadah di rumah. Pendekatan kualitatif dengan metode metodologi dipakai untuk mendapatkan pengajaran dari pengalaman tersebut bagi sisi spiritualitas. Dengan sample seratus responden dari empat jemaat yang mengadakan ibadah di rumah, di temukan hasil diantaranya menyadari kesempatan untuk melihat kuasa Tuhan atas seisi dunia, dansemakin berserah pada-Nya (sekitar 94\%). Komposisi responden didominasi mengikuti ibadah dengan live streaming (92\%) sedangkan ibadah di rumah dengan tata ibadah dari gereja sebanyak $5 \%$. Dari sejumlah responden didapati 2,6\% berbagi Firman Tuhan (sharing) pada sesi khotbah dalam kebaktian di rumah. Dengan penelitian ini ada harapan kepada gereja-gereja untuk menatap dengan serius bidang digital dengan (misalnya) membentuk komisi/sie khusus digital atau sebutan lain dengan tugas pada pelayanan dunia daring karena kemajuan teknologi informasi menjadi tools yang tidak dapat diabaikan demi kemajuan pelayanan dan perkembagan gereja. Masa pandemik tidak menjadi ancaman kepada warga jemaat untuk bertumbuh dan bergegas dalam sisi spiritualitas.
\end{abstract}

Kata Kunci: spiritualitas, fenomenologis, pandemik, ibadah di rumah.

\section{PENDAHULUAN}

Secara umum dapat dikatakan bahwa warga gereja memulai ibadah di rumah sejak 22 Maret 2020. Keputusan ini sebagai konsekuensi dari Surat Edaran Kementerian Kesehatan (SE Kemenkes) tanggal 16 Maret 2020 yang kemudian anjuran Presiden agar masyarakat Indonesia bekerja dari rumah, belajar dari rumah dan beribadah di rumah. Karena itu Gereja berupaya agar pelayanan kepada jemaat tetap terlaksana namun tidak mengabaikan anjuran pemerintah, misalnya agar memperhatikan jarak sosial (social distancing) dan jarak fisik (physical distancing), serta tak jarang di gereja menghindari kerumunan orang dalam satu ruangan. Untuk memberikan pelayanan yang terus dan mengena kepada umat, dalam situasi apapun Gereja tidak boleh berhenti dalam penatalayanan sebagai bagian penggembalaan. Apa yang disebut oleh Messakh dengan "pe- 
layanan pastoral dan pendampingan pastoral" (Messakh, 2018, pp. 26-28) dalam situasi ini harus diberikan oleh Gereja tentunya. Untuk penjelasan pendampingan pastoral Nuggroho menjabarkannya dengan lebih terperinci (Nugroho, 2017). Berbagai upaya gereja tersebut dikerjakan untuk kemaslahatan kesehatan umat dan terputusnya rantai penyebaran virus korona jenis baru itu (SARS-CoV-2).

Fenomena beribadah di rumah tampak di banyak tempat diIndonesia, bukan saja Gereja tetapi tempat ibadah lainnya juga ikut mengindahkan anjuran pemerintah tersebut. Di kota Medan, hampir tidak ada ditemukan Gereja yang mengadakan kebaktian pada hari minggu, termasuk dalam pelayanan Ibadah Rumah Tangga (ada yang menyebut Komsel, Perpulungen jabu-jabu/PJJ, Family Altar dan berbagai sebutan lainnya) sejak minggu ketiga Maret ditiadakan. Untuk ibadah minggu pelak-sanaannya di rumah masing-masing dengan panduan tata ibadah dari gereja masing-masing. Sebagian lagi mengupayakan melalui live streaming ditayang dengan aplikasi youtube, facebook atau instagram.

Meski dapat diterima untuk situasi sekarang ini, karena dampak dari mewabahnya virus korona jenis baru, namun ibadah live streaming dan atau yang direkam lebih dahulu lalu disiarkan, ternyata model ibadah ini menimbulkan banyak pertanyaan dan kesan teologis yang patut untuk dipaparkan. Apakah ibadah dengan berbagai model daring tersebut berkenan kepada Allah? Bagaimana Rumah Ibadah (Gereja, Masjid, Vihara, Klenteng, Kuil) mensiasati situasi sekarang ini berdasarkan Kitab Suci? Jika Kitab Suci tidak secara harafiah memberikan ajaran untuk ibadah dengan berbagai model daring tersebut, mengapa Pemimpin Agama menganjurkannya? Apa upaya-upaya Rumah ibadah agar penatalayanan terhadap jemaat tetap berjalan meski situasi tidak sebagaimana biasanya? Karena berbagai kalangan beranggapan ibadah di tempat ibadah jauh lebih khusyuk, jauh lebih nikmat daripada beribada dari rumah meski dengan Tata Acara yang dikeluarkan oleh tempat ibadah, seperti Gereja. Pertanyaanpertanyaan ini masih diperkeruh dengan perdebatan diantara jemaat dengan pemimpin agama perihal kudus tidaknya ibadah dari rumah dengan model daring. Bahkan ada pula yang saling klaim mampu mengatasi wabah virus korona jenis baru ini dengan kebiasaan ibadah yang diajarkan di tempat ibadahnya. Sebaliknya, jauh sebelum work from home (wfh) diberlakukan pemerintah Indonesia, pengguna media sosial dalam hal ini facebook, untuk tujuan penginjilan, telah dipakai hampir 5\% dari pengguna facebook di Indonesia. Penelitian Octavianus menunjukkan bahwa pengguna aplikasi "yesHeis" di facebook (Octavianus, 2018, p. 73) sebagai indikasi bahwa bentuk-bentuk pelayanan Kristen dan pemberitaan Firman atau keperluan bidang-bidang lainnya mempunyai 'jemaat' tersendiri yang jumlahnya tidak bisa dibilang sedikit. Terkait maraknya penggunaan media dalam pelayanan, Ronda memberi tekanan agar pemimpin kristiani agar mengupayakan memahami dan merangkul dunia digital, bukan sebaliknya (Ronda, 2016, p. 194). Tentu ini salah satu upaya yang efektif jika ingin memperngaruhi dunia dan masa yang akan datang.

Tulisan ini mencoba memberi pemaparan dari pertanyaan-pertanyaan pada alinea sebelumnya dengan fokus kepada fenomena yang terjadi yaitu ibadah di rumah. Bagaimana spiritualitas jemaat dari model pelayanan baru ini. Sehingga umat menemukan satu makna baru dari fenomena beribadah di rumah konsekuensi dari ditetapkannya pandemi di Indonesia. Penelitian ini terdorong dari penelitian sebelumnya dimana Widjaja et al. (2020, p. 137) mendorong agar ada penelitian baru pada segmen berbeda berangkat dari adanya fenomena baru yakni ibadah di rumah. Dalam penelitiannya Widjaja menemukan bahwa gereja di rumah menjadi satu strategi misi dalam menjangkau orang-orang selain memperkuat sendi keluarga Kristen (Widjaja et al., 2020, p. 136).

\section{METODE}

Metode yang digunakan dalam penelitian ini adalah metode penelitian fenomenologi, pendekatan kualitatif. Lincoln dengan singkat menyebut penelitian fenomenologis ini sebagai penelitian berbasis 
bukti dan sekaligus pengajaran berbasis bukti (Lincoln, 2011, p. 186). Patilima memberi penjelasan dan batasan lebih detail, yakni penelitian ini mencakup penggunaan subjek yang dikaji dan kumpulan berbagai data empiris studi kasus, pengalaman pribadi, introspeksi, perjalanan hidup, wawancara, teksteks hasil pengamatan, historis, interaksional, dan visual yang menggambarkan saat-saat dan makna keseharian dan problematika dalam kehidupan seseorang (Patilima, 2016, p. 3). Hamzah meminjam dari Bertens, menyatakan fenomenologi adalah studi tentang esensi-esensi, misalnya esensi persepsi, esensi kesadaran, dan sebagainya (Hamzah, 2020, p. 10). Masih menurut Hamzah (2020, p. 98) tahapan awal dari penelitian ini, selain mengkaji literatur, dalam pengumpulan data dilakukan dengan wawancara kepada partisipan. Sedangkan analisa terhadap fenomena dari data yang terkumpul tah-pannya adalah; pertama mendeskripsikan pengalaman, kedua menemukan pernyataan dari hasil wawancara, ketiga mengelompokkan pernyataan-pernyataan yang sama, keempat merefeleksi pemikiran dan mencari keseluruhan makna atas fenomena dan kelima mengonstruksi seluruh penjelasan tentang makna dan seluruh pengalamannya. Dalam suasana pembatasan sosial dan jarak antar orang saat ini, maka wawancara terstruktur guna memperoleh data dilakukan dengan applikasi google form partisipan. Namun peneliti tetap mengusahakan wawancara yang mendalam (indepth interview) terhadap 5 orang partisipan (Hamzah, 2020, p. 68) untuk melengkapi data sebelum tahap interpretasi (Hamzah, 2020, p. 105). Wawancara secara mendalam dibutuhkan untuk menggali informasi atas temuan-temuan yang memerlukan penggalian dari partisipan yang dianggap kaya (information rich) serta dapat dipercaya (credible) akan informasi untuk memahami arti dari pengalaman partisipan (Raco, 2010, p. 117). Peneliti menentukan seratus partisipan atau responden sampel dari penelitian ini di kota Medan yakni dua jemaat HKBP dan dua jemaat GBI. Penentuan partisipan ditentukan secara purposive sampling sesuai dengan kriteria yang diinginkan oleh peneliti dan tentu setelah par- tisipan menyetujui maksud peneliti. Pemilihan HKBP dan GBI secara random setelah ditelusuri dari beberapa Gereja, keduanya melaksanakan ibadah $l i$ ve streaming. Zaluchu menegaskan pengalaman partisipan menjadi acuan pengamatan dalam penelitian dengan pendekatan fenomenologi (Zaluchu, 2020, p. 36). Sedang di bagian akhir akan dipaparkan makna dari temuan fakta atas data dari responden yang diwawancara. Interpretasi terhadap data mentah maupun hasil reduksi guna mengungkap lebih dalam penomena ibadah dari rumah (Laverty, 2003, p. 24).

\section{HASIL DAN PEMBAHASAN/ISI}

Pada bagian ini akan dipaparkan lebih dahulu kajian terhadap kata spiritualitas dan ibadah di rumah. Akan dijelaskan fakta Alkitab tentang ibadah di rumah yang ada di Perjanjian Lama dan Perjanjian Baru.

\section{Spiritualitas Pandemik}

Pailang ( 2012, p. 59) memberikan lingkup bagi kehidupan spiritualitas sebagai satu upaya yang terus menerus untuk mendemonstrasikan hidup yang berarti atau bermakna dengan menjaga dan memelihara iman serta faktor-faktor yang berkaitan dengan seseorang atau komunitas supaya dapat mengambil sikap dan keputusan dalam realitas hidup di tengahtengah tantangan dan kesempatan dalam kehidupan. Hal ini berarti spiritualitas mengambil cakupan yang dapat berbeda dari satu komunitas, orang per orang berdasar situasi yang berbeda. Ada banyak faktor perhatian yang terkait terhadap spiritualitas seseorang atau komunitas dan dapat mengalami beberapa perbedaan jika situasinya berbeda. Singkatnya, Djadi (Djadi, 2012, p. 110) spiritualitas seseorang adalah menyangkut kehidupan rohani. Karena itu untuk pelayan Tuhan (full timer), terkait pada spiritualitasnya adalah kehidupan rohani atau disiplin rohani atau hubungan pribadi dengan Allah yang dilakukan secara konsisten oleh seorang pelayan Tuhan atau orang yang terpanggil untuk melayani Tuhan dalam seluruh aspek kehidupannya, baik secara formal maupun nonformal (Djadi, 2012, p. 110). 
Bagi kaum evangelikal, spiritualitas bahkan bisa menjadi seperti kerikil-kerikil di bawah sepatu, karena bagi kaum injili aspek spiritualitas adalah aspek krusial yang harus diperhatikan selain doktrin (E. Gunawan, 2013, p. 17). Bahkan spiritualitas menyentuh hingga pada tercapainya keseimbangan antara personal dan komunal. Dari beberapa pengertian sebelumnya, peneliti melihat bahwa spiritualitas dapat digambarkan sebagai keberadaan titik imani seseorang yang terpancar jelas dari kehidupannya, baik menyangkut hubungannya dengan Allah, orang lain maupun alam yang di sekitarnya. Stott memberi perhatian tersendiri terhadap topik ini dari delapan aspek yang sering diabaikan oleh orang Kristen (Stott, 2010, pp. 45-54 Bab IV.). Mazmur 24:1 menuliskan "Tuhanlah yang empunya bumi. Dibagian lainnya ditulis, "Langit itu langit kepunyaan TUHAN, dan bumi itu telah diberikanNya kepada anak-anak manusia” (Mzm. 115:16). Karena itu tanggung jawab yang diberikan Allah ini hendaknya dilihat sebagai sebuah tanggung jawab pelayanan, bukan mengabaikan apalagi menghancurkan. Jika pemeliharaan terhadap alam ini tercapai, menunjukkan bahwa kerjasama manusia dengan Allah telah terjalin (Stott, 2010, p. 48).

Dengan memperhatikan situasi pandemik sekarang ini, maka spiritualitas seseorang juga dapat dihubungkan dengan sikapnya sebagai umat Allah dalam berelasi dengan orang lain, baik di lingkup masyarakat (tempat tinggal atau sesama warga jemaat di satu gereja tertentu) dengan menujukkan perhatian dan relasi yang hangat di dalam nama Yesus. Dari tulisan Gunawan, memberi cakupan yang lebih spesifik, bahwa spiritualitas diharapkan akan menjadi spiritualitas yang utuh, dengan penekanan yang lebih seimbang antara inward dan outward, antara personal dan komunal, dan yang terutama, bersumber dari pemahaman doktrin yang tepat (E. Gunawan, 2013, p. 35). Sementara itu teolog injili Kapic mengutarakan bahwa teologi yang benar itu selalu harus merupakan spiritualitas sejati (Kapic, 2014, p. 37). Hidupnya akan tercemar bila pancaran dalam hidupnya bukan merupakan ekspresi isi hati Sang $\tau \dot{\varepsilon} \delta$ ó (Teos) yang tertulis di Alkitab.

Jadi esensi dari spiritualitas (Nugroho, 2019, p. 109) bukan hanya tingkat pemahaman tentang Tuhan, melainkan implikasi kehidupan yang mengejewantahkan ajaran Tuhan dalam sikap dan perilakunya setiap hari. Di sinilah tugas dari agama (gereja) untuk dapat memberdayakan jemaat, agar mampu meningkatkan spiritualitasnya, sebagai ketahanan iman dalam meningkatkan presistensi dan eksistensinya dalam memperjuangkan iman di tengah realitas sosial yang ada. Dengan situasi bagaimanapun, Gereja tetap menjaga pelayanan tetap berjalan demi kelanjutan spiritualitas jemaat, khususnya dalam era pandemik korona. Waktu yang tidak bisa terulang, harus terus diupayakan agar meninggalkan momen berharga dalam progresifitas spiritual warga jemaat (Band. Sutoyo, 2018). Dalam menggunakan waktu, Sutoyo memberikan nasihat agar tidak menunda mengerjakan pekerjaan yang diberikan $\mathrm{Tu}$ han, misalnya perintah untuk berdoa, merenungkan Firman Tuhan, mengabarkan Injil, terus bekerja, setia dalam pelayanan pekerjaan TUHAN, berdiakonia, menjalin koinonia dan yang lain. Pekerjaan-pekerjaan ini jangan ditunda sampai hari besok sebab barangkali besok tidak ada kesempatan untuk menuntaskannya (Sutoyo, 2018, p. 47). Dalam hal ini, spiritualitas kristiani sangat berkenaan dengan implementasi kompetensi, kesempatan dan panggilan khusus dari Tuhan terhadap setiap orang secara berbeda. Satu eksistensi kerohanian akan terlihat dari ekspresi spiritualitasnya dalam sehari-hari, dalam segala situasi kepada keluarga, lingkungan, bangsa-negara dan terhadap gereja tentunya. Sebab mengukur spiritualitas kekristenan itu lebih merupakan sebuah perjalanan yang dinamis, bukan pencapaian yang statis menuju keserupaan dengan Kristus (Budijanto, 2018, p. 23).

\section{Pademi Covid-19}

Dengan jumlah 11.425.209 orang terkonfirmasi positif Covid-19 di 216 negara (https://covid19.go.id/.,akses 7-Juli-2020), penyakit ini tidak 
bisa dianggap remeh. Sedangkan di Indonesia 66.226 terkonfirmasi positif dan menelan korban jiwa 3.309 orang. Mulai dari perayaan Imlek tidak maksimal di China, orang-orang tidak melakukan tradisi mudik disana hingga kebaktian peringatan kematian Yesus serta perayaan Paskah juga sepi dari kisah pesta pencarian telur, terakhir bulan Ramadhan hingga perayaan Idul Fitri dianjurkan agar ibadah dilakukan di rumah saja. Fakta ini menjadi konfirmasi bahwa virus korona jenis baru (SARS-CoV2) yang mengakibatkan sakit covid-19 adalah fenomena baru sebagai ancaman terhadap rutinitas keagamaan yang tidak terbantahkan pada semester pertama tahun 2020 .

WHO memberi nama virus tersebut severe acute respiratory syndrome coronavirus-2 (SARSCo-V-2), dan para ahli berpendapat (Yuliana, 2020, p. 188) bahwa transmisi pneumonia mudah tertular ke orang lain sedangkan bagaimana virus dengan mudah menular masih misterius dan penelitian tentang korona masih terus berlanjut. Hick dan Paul D. Biddinger (Hick \& Biddinger, 2020, p. 3) memberi nasihat yang perlu dipertimbangkan tentang keganasan virus ini, yakni agar semua elemen masyarakat berhati-hati dan lebih bertanggung-jawab atas kesehatan dirinya sebab wabah ini bisa berakibat satu tahun atau bisa juga dua puluh tahun setelahnya.

Dengan gambaran penularan yang cepat serta korban yang ditimbulkan, Gereja sekali lagi perlu mengkaji kembali jadwal-jadwal kebaktian serta prosedur/protokol yang ketat jika ingin mengaktifkan kembali ibadah di gedung gereja secara bersama-sama. Hingga kini belum ada vaksin untuk itu, maka usaha memutus rantai adalah dengan melaksanakan ibadah di rumah melalui koordinasi dari gereja, baik tata ibadah, penyerahan persembahan, pembacaan warta jemaat untuk terjalinnya unsur koinonia dalam ibadah tersebut meski masingmasing keluarga ibadah di rumahnya.

Dalam situasi pandemi ini, umat Kristen diperhadapkan kepada tetap beribadah di Gereja namun menuai potensi penularan semakin besar jika keluar dari rumah. Di sisi lain liniearitas spiritual te- tap berjalan karena beribadah kepada Allah secara personal maupun komunal adalah wujud ekspresi iman Kristen. Perjalanan spiritual umat menemukan tantangan yang tidak mudah untuk dijawab dengan hanya ke gereja dan beribadah atau tetap di rumah saja tanpa beribadah.

\section{Ibadah di Rumah dalam Lintas Sejarah dan Kitab Suci}

Dalam Alkitab, mengenal ibadah secara komunal (berjemaah) dan personal. Ibadah secara komunal yang tampak misalnya kebaktian di Gereja dan kebaktian rumah tangga. Ibadah komunal telah dikenal sejak kitab Kejadian namun dilakukan dengan peserta lingkup keluarga atau suku. Abram misalnya beberapa kali mendirikan mezbah dalam perjalanannya bersama keluarga ketika merespon panggilan Allah Yahweh untuk menuju tanah yang akan dituntunNya. Abram, bapa Leluhur dicatat dalam Kej.12:8 di sebelah timur Betel; lalu 13:18 di Mamre mendirikan kemah untuk ibadah keluarga dan orangorang yang bersama dengannya. Pada masa itu menurut Rowley, tidak satupun perikop-perikop tersebut menuliskan bahwa mezbah-mesbah itu dikepalai oleh seorang imam (Rowlley, HH, 2012, p. 16). Karena itu diduga kepala keluarga adalah imam dalam ibadah-ibadah yang diselenggarakan. Fakta ini menjadi menarik karena jadi model bagi pola ibadah dari rumah sekarang ini yang tengah diterapkan banyak gereja. Ibadah komunal ini semakin dipahami bentuknya setelah orang Israel menuju tanah Kanaan. Allah kemudian memberikan berbagai peraturan keimaman dalam Kitab Imamat dan Bilangan, lalu diulang kembali dalam kitab Ulangan secara khusus sebelum bangsa itu dari generasi yang baru lahir selama di padang gurun.

Salah satu pertimbangan sebagai tempat ibadah dalam Perjanjian Lama adalah dimana Allah menyatakan diri-Nya (Drane, 2017, p. 87). Karena itu tempat khusus dimaknai kudus jika umat Allah meyakini dapat bertemu dengan Yang Maha Kudus dengan aman. Pemaknaan tempat ibadah ini masih berlanjut hingga masa Hakim-hakim. Karena meya- 
kini kehadiran-Nya dianggap sebagai wujud menyelamatkan umat-Nya (Ing, 2012, p. 37). Dapat dipahami bahwa tempat ibadah merupakan impian yang terdapat dalam benak umat di Perjanjian Lama karena disana Allah hadir untuk memberi keselamatan, dan tempat itu adalah kudus karena kehadiranNya, bukan bentuk bangunan atau sarana yang tersedia.

Dari keyakinan itu sangat beralasan jika orang Israel khususnya berhati-hati dalam menentukan tempat ibadah karena menyangkut representasi Yahweh dan penyataan kuasa-Nya. Ketika orang Israel berada di sekitar bangsa-bangsa yang menyembah Baal, ibadah yang disaksikan dari peribadahan bangsa-bangsa, menurut Hinson mengundang sentimen Israel dengan alasan, pertama ibadah-ibadah kepada Baal dapat mempengaruhi imannya dan murtad dari Tuhan. Kedua, memiliki potensi untuk mengurangi ketaatan orang Israel kepada Tuhan (Hinson, 2014, p. 152). Sebab ibadah kepada Baal dapat dilakukan di tempat-tempat yang ditentukan kemudian oleh ilah sesembahan. Sehingga anak-anak Israel dapat menyaksikannya karena di tempat terbuka yang mungkin saja di tempat terbuka.

Dari fakta ini terlihat bahwa tempat ibadah di Perjanjian Lama berdasarkan kehadiran Allah dan keyakinan, mengimani bahwa Allah yang disembah adalah Allah yang mampu memberi keselamatan. Pada hemat peneliti tempat menjadi kudus jika Allah sungguh hadir dalam ibadah yang diselenggarakan. Karena itu faktor hadirnya Allah dan iman terhadap Allah yang disembah menjadi pertimbangan dalam menyelenggarakan ibadah.

Sedangkan Ibadah personal bentuknya banyak sekali; seperti doa sebelum dan sesudah tidur, berpuasa secara pribadi untuk pergumulan tertentu atau dengan sengaja menyanyi di rumah dengan sukacita atas berkat Allah yang melimpah. Dalam Alkitab pola ibadah personal juga bisa ditemukan. Tokoh Ezra adalah salah satu contoh dari kaum awam yang tekun dalam doa, pembacaan dan pendalaman Kitab Suci secara pribadi dalam Perjanjian Lama. Ketokohan serta kepiawaian Ezra dalam me- mahami kitab Suci kemudian menjadi cikal bakal kelompok yang dikenal di Perjanjian Baru pada era Yesus yaitu kelompok ahli Taurat. Contoh lain yang memberitahu tentang ibadah personal adalah Nyanyian Pemazmur. Daud menuliskannya demikian, "TUHAN, pada waktu pagi Engkau mendengar seruanku, pada waktu pagi aku mengatur persembahan bagi-Mu, dan aku menunggu-nunggu" (Maz. 5:4). Fakta ini menjadi dasar bahwa Allah menghendaki umat-Nya datang beribadah kepada-Nya, baik secara komunal keluarga maupun berjemaah, dan secara personal.

Dalam catatan Alkitab, jalannya ibadah itu secara umum dipimpin oleh imam. Perjanjian Baru tampaknya dalam hal ini masih meneruskan tradisi Perjanjian Lama, yakni sinagoge menerapkan penjadwalan terhadap pemimpin ibadah. Ferguson menerangkan profil seorang imam sebagai orang yang menerima hak istimewa dengan salah satu tugasnya adalah berdoa kepada Allah di sorga bagi orang (Ferguson, 2017, p. 234). Bahkan penentuan imam yang terus dipakai dimasa agama Yunani adalah jika dia mampu untuk mendekati dewa. Yesus Kristus memakai kebiasaan imam yang turun dari sinagoge setelah jadwal pelayanan (Luk.10:31), sebagai bagian kisah dalam perumpamaan Orang Samaria yang baik hati. Ini berarti Imam masih memimpin berbagai ibadah yang diadakan di sinagoge dengan berbagai jenis ibadah dibait Suci Yerusalem (Hutahaean, 2016a). Novel Rohani Kristen berjudul Quo Vadis Domine, mengisahkan bahwa pada masa Kaisar Nero, hingga Kaisar Vespasianus dan Kaisar Trajan (kurun waktu thn.50 sd 125-an), kehidupan peribadahan umat Kristen dalam keadaan terintimidasi dan sarat kekerasan dengan pembunuhan keji. Sehingga waktu itu imam harus memimpin dengan sangat hati-hati, bahkan beberapa kali masih memimpin ibadah di gedung-gedung tersembunyi dengan nyanyian yang hampir tidak kedengaran. Adapun pembacaan mazmur juga hampir tanpa ada, meski tetap dinyanyikan seturut kebiasaan kala itu. Tradisi ini menunjukkan pentingnya imam dalam memimpin ibadah dalam peribadahan kristiani. Bersyukur, sete- 
lah Kaisar Konstantianus menjadi Kristen pada tahun 313, kemudian agama Kristen dijadikan agama Negara, memberikan kebaktian tidak lagi momentum yang menakutkan bagai pertaruhan nyawa.

Dari data singkat tersebut dapat dipahami bahwa ibadah dalam kekristenan adalah ibadah yang dijalankan dengan tata ibadah (bernyanyi, membaca mazmur, doa, khotbah) tertentu dan dipimpin oleh imam (pemimpin ibadah). Meski demikian, masih dapat menemukan adanya ibadah-ibadah yang pelaksanaannya tidak seperti peribadahan secara umum. Hal ini bisa kita temukan dari pernyataan Allah melalui Amos ketika mengatakan, Apakah kamu mempersembahkan kepada-Ku korban sembelihan dan korban sajian... hai kaum Israel?" (Am. 5:25). Purba dalam akun media sosialnya menerangkan tentang nats ini dengan baik. Menurut Roy F Purba Allah bukan berarti tidak mementingkan korban dalam ibadah umat Israel. Dari dahulu sejak zaman bapa leluhur Israel, kurban bakaran adalah cara persembahan yang diinginkan Allah dari umat-Nya. Namun untuk masa perjalanan Israel dari Mesir menuju Kanaan selama 40 tahun, ada dispensasi yang diberikan Allah dalam peribadahan-peribadahan mereka. Sebab dalam perjalanan di padang gurun, tentu sulit untuk memenuhi syarat yang mutlak bagi Allah diantaranya menyediakan berbagai hewan yang tidak bercacat sebagai korban dalam ibadah yang dilaksanakan. Jika dilihat ke belakang lagi, Allah juga meminta agar Israel menetapkan enam Kota Perlindungan untuk dijadikan tempat pengasingan (Bil. 35:9-15) untuk orang-orang yang membunuh dengan tidak sengaja. Di tota-kota ini tidak ditempatkan orang Lewi untuk memimpin ibadah bagi mereka selama waktu yang lama. Dan orang-orang di kotakota perlindungan tersebut menurut catatan Maz. 27:5-6 boleh mengadakan persembahan dengan membakar sendiri persembahan korba. Padahal korban bakaran kepada Allah, hanya boleh dilaksanakan oleh imam yang ditentukan, misalnya dari kaum suku Lewi. Namun dalam kondisi tertentu, dalam hal ini di kota perlindungan, membakar korban persem- bahan boleh dilakukan oleh bahkan orang yang telah melakukan pembunuhan, meski tidak disengaja.

Dari kisah pasca kenaikan Yesus, ibadah di rumah-rumah adalah bagian dari bentuk ibadah yang diadakan dalam situasi tidak lazim. Ibadah di rumah dengan rasa ketakutan luar biasa terhadap penguasa, Kaisar yang lalim, menghadirkan ibadah tanpa lagu yang nyaring, kebaktian dengan rasa curiga sesama umat dalam rumah atau tempat tertentu. Pada masa pasca kenaikan Yesus, sinagoge tidak lagi menjadi tempat pemberitaan Firman oleh para rasul dan murid-murid yang tak terhitung banyaknya setelah peristiwa Pentakosta (KPR.2).

Dengan fakta diatas maka pertama, bahwa ibadah secara personal dan komunal menurut catatan Alkitab adalah ibadah yang dikehendaki Allah. Jika diadakan secara personal maka keberadaan imamat ada pada diri yang bersangkutan. Demikian pula ibadah secara komunal dapat juga kepala keluarga menjadi imam dalam ibadah itu. Kedua, untuk situasi yang tidak lazim, diluar kebiasaan, nalar serta kendali manusia, maka ibadah boleh saja diadakan inovatif. Misalnya tanpa imam yang ditugaskan/ ditahbiskan atau tidak mengikuti tata ibadah secara komplit. Meski tata ibadah tidak lengkapseperti di rumah ibadah/gereja, bukan berarti mengurangi nilai kekudusan dari ibadah itu. Karena itu pada masa kini inovasi ke ibadah di rumah dengan mengikuti live streaming adalah salah satu bentuk yang dimaksud dengan inovasi. Sebab, Roh Kudus datang kepada umat-Nya dan menghadiri ibadah bukan terletak kepada persiapan para pelayan dan prasa-rananya, namun seturut Konfrensi Gereja Lutheran dalam sidang di Ausburg (tahun. 1530), adalah melalui "firman Injil yang nyata" (Tappert, 2016, p. 39). Dalam pemaparan yang lebih luas, Setiawan (Setiawan, 2013, p. 172) menyatakan bahwa Allah Tritunggal hadir dalam suatu ibadah secara unik. Tiga dasar teologis Jimmy yakni pertama Bapa memegang posisi primacy dari semua devosi umat. Kedua, Yesus Kristus menjalani peran mediacy dan Imam untuk mengantarai dengan Bapa, sedangkan ketiga Roh Kudus menolong jemaat untuk bersatu dengan Bapa 
serta menyembah-Nya dengan benar (Setiawan, 2013, p. 173).

Dari penelusuran ini memiliki kesamaan dalam praktek dan ideologi bagi ibadah di rumah. Yakni; pertama kehadiran Allah dalam Ibadah menjadi alasan bahwa ibadah di rumah tidak mengurangi nilai rohani dan kekhusukkannya. Karena itu kudus tidaknya satu ibadah tidak bersyarat pada tempat, sarana-prasarana yang digunakan. Kedua, mengikuti ibadah di luar gedung Gereja telah menjadi model ibadah pada masa Perjanjian Lama, Perjanjian Baru dan beberapa ratus tahun psca Yesus. Praktek ini juga dapat dipergunakan sebagai sarana misi keluarga untuk membawa orang pada Yesus. Ketiga, beribadah di tempat yang ditentukan gedung Gereja, memiliki konsekuensi sosial yang lebih besar, misalnya merajut silaturahmi dengan jemaat yang lain melalui tegur sapa. Karena itu, ibadah di Gereja harusnya kembali dilakukan jika masa pandemi telah berlalu. Sebab peneliti meyakini bahwa masa darurat (pandemi) ini jemaat baiknya beribadah di rumah namun praktek itu hendaknya tidak memiliki tujuan untuk menggantikan beribadah di Gereja.

\section{Pengajaran Kepada Umat Terhadap Ibadah dari Rumah}

Perbedaan pandangan diantara umat dan para Pendeta Jemaat tidak bisa dipungkiri terkait ibadah di rumah. Dalam praksisnya adalah ada gereja yang tetap mengadakan ibadah di gereja (on site) dan mengadakan ibadah di rumah dengan live streaming. Di Medan mayoritas ibadah dilakukan di rumah. Namun tidak sedikit yang tetap mengadakan ibadah di Gereja, sejak ditetapkannya pandemi korona pada pertengahan Maret.

Di bagian sebelum telah dipaparkan bahwa ibadah di rumah tidak mengurangi kedekatan, kekhusyukan jemaat kepada Tuhan. Namun karena umat telah puluhan tahun bahkan ratusan tahun memahami dan melihat fakta ibadah dalam satu gedung secara bersama-sama (berjemaah) maka ada perbedaan rasa dan kesan setelah Rumah Ibadah/Gereja memberlakukan ibadah dari rumah dengan live streaming. Meski demikian, ibadah dari rumah dengan live streaming bukanlah ibadah yang menjadi impian untuk menggantikan ibadah bersama-sama di satu gedung. Sebab persekutuan kristiani itu muncul dalam bentuk berkumpulnya orang banyak dalam satu kegiatan melalui tata ibadah, sebab dengan demikian satu sama lain merasakan kedekatan yang luar biasa di dalam Kristus (Siringoringo, 2016, p. 99). Perbedaan suku, marga, kelas sosial dan warna kulit telah terbukti ampuh memudar dalam kedekatan yang ditimbulkan oleh persekutuan ibadah di gedung bersama-sama seperti Gereja. Dalam sejarah Gereja, kedekatan karena pemahaman teologi dan aliran yang sama menjadi urutan pertama dalam perkembangan gereja (Hutahaean, 2016c). Kemudian diikuti keterkaitan secara tradisi, persamaan liturgi serta tata pemerintahan gereja. Ini menjadi gambaran mengapa ada kesan yang berbeda jika peribadahan dipindah secara per keluarga dengan secara bersama-sama di gedung Gereja. Ikatan emosional ternyata dapat muncul dari kebersamaan yang terjadi dalam satu persekutuan dalam Yesus Kristus. Hal ini dipertegas lagi oleh Silitonga yang menyatakan bahwa dalam masa Covid-19 ibadah di rumah merupakan tanggung jawab cultural dan peradaban di bumi selain menjadi bagian penting dalam ibadah gerejawi (Silitonga, 2020, p. 98).

Dalam satu penelitian Hidajat dipaparkan fungsi rumah dari tinjauan Perjanjian Baru. Selain fungsi ekonomi, Hidajat menjelaskan bahwa dalam $\mathrm{PB}$ ada fungsi sosial dan religius. Fungsi religius ini tampak dengan pemanfaatan rumah untuk bergereja. Bahkan ada sisi positif penggunaan rumah sebagai tempat pertemuan (Hidayat, 2018, p. 114). Paulus dapat menjangkau di dalam rumah-rumah yang disinggahinya. Pos memberikan penjelasan tentang metafora Rumah dari Alkitab. Ajaran yang dikandung dalam metafora rumah misalnya rumah adalah rumah rohani yang sedang dibangun dengan batubatu hidup. Paulus memakai metafora "bait Allah" (1 Kor. 3:1-17; Ef. 2:21-22) karena semua orang percaya, dibangun menjadi satu bait Allah (Pos, 
2018, p. 769). Dari beberapa fakta diatas peneliti menyatakan bahwa rumah sebagai tempat beribadah pada masa pandemik seperti sekarang ini bukan satu fenomena yang benar-benar baru. Beribadah di rumah merupakan kilasan ulang dari fakta sejarah yang pernah dilalui. Perlu menyemai nilai teologis dalam peristiwa ini untuk menuai buah spiritualitas dalam kehidupan warga gereja. Dari sisi peluang, momen ini memberi kesempatan kepada pemimpin gereja dapat mengupayakan satu usaha yang kreatif demi pertumbuhan gereja melaluinya (Hutahaean, 2016b). Meski ibadah di rumah bukan satu ekspektasi yang diharapkan, apalagi sengaja dirancang untuk menggantikan peribadahan secara bersamasama di gedung gereja.

Untuk itu ada yang harus dipaparkan kepada umat sehingga menikmati kekudusan dan kekhusyukkan ibadah dari rumah. Dalam tulisan ini mengajukan tiga pokok yakni: Pertama, ibadah dari rumah adalah alat bagi Allah untuk umatnya, tetap menikmati hadirat Allah dalam persekutuan yang lebih kecil yaitu keluarga. Pada ibadah bentuk ini, hubungan erat antar keluarga kian dipupuk, sehingga lebih kuat dan segar. Hubungan dituntut untuk lebih hangat karena Allah tentu lebih menyukai keterusterangan jemaat yang datang kepada-Nya. Aspek koi-nonia dari ibadah dari rumah, tidak kehilangan semua langkahnya, sebab dengan membaca warta yang sama, memberikan atau menyerahkan persembahan kepada gereja yang sama, menyanyikan lagulagu bersama, mendengarkan nats khotbah yang sama pula dengan warga jemaat lain meski di rumah yang berbeda-beda. Tentu pertemuan fisik dengan rekan sesama kaum bapak atau sesama pemuda tidak ditemukan lagi dalam bentuk ibadah dari rumah.

Kedua, masing-masing kepala rumah tangga (termasuk ibu), mempersiapkan diri dengan tugas sebagai pemimpin ibadah secara bergantian. Tidak hanya disitu, tetapi perlu memberi pemahaman kepada seisi rumah sejak Sabtu sehari sebelum kebaktian, dan sesaat setelah kebaktian dari rumah bahwa ibadah dari rumah tidak kalah kekudusannya dengan ibadah di Gereja. Bukankah Ulangan 6:7 ju- ga memberikan prinsip, "mengajarkannya berulangulang kepada anak-anakmu" dapat diterapkan untuk segmen ini? Jika di Gereja sebagian besar umat adalah peserta yang mengikuti tata ibadah dan arahan imam (parragenda, liturgos, penyembah, pemuji dlsb), maka ibadah dari rumah sebaliknya. Lebih banyak lagi anggota jemaat mengambil peran mengatur ibadah, mengawasi peserta ibadah dan ada rasa tanggung-jawab agar ibadah terselenggara dengan khusyuk dan lancar.

Ketiga, dari era megalitikum hingga era quantum, perubahan dan sikap terhadap perubahan menunjukkan siapa sebenarnya seseorang. Baik dari sisi iman, kesehatan, maupun kemampuan beradaptasi terhadap stimulan. Efferin dalam satu tulisannya menyikapi adanya perubahan yang tidak bisa dihindari oleh Gereja. Menurut Efferin perubahan adalah suatu keniscayaan, tidak terhindarkan. Dalam menyikapi perubahan semua orang harus memulai dengan semangat positif dan bijaksana. Menghadapi perubahan itu, seseorang harus fokus pada panggilan surgawi (Efferin, 2013, pp. 89-90). Situasi sekarang ini bukan hanya di sebagian belahan dunia, atau menimpa Negara Asia Tenggara saja. Bukan pula diderita oleh umat Kristen atau agama tertentu lainnya. Anjuran social distancing dan physical distancing didengungkan kepada semua orang di semua benua di dunia. Dengan harapan agar secepatnya rantai penularan virus korona jenis baru terputus. Karena itu situasi sekarang berbeda dengan situasisituasi pada beberapa contoh diatas dalam lintasan sejarah dan fakta Alkitab. Karena itu, untuk mencapai apa yang disebut feel good dalam menjalani ibadah dari rumah, mengutip Adi W Gunawan, yaitu untuk menumbuhkan rasa syukursalah satu langkah penting untuk dapat bersyukur, (A. W. Gunawan, 2017, pp. 183-191. Baca juga bab 9 dan 10), adalah tidak membandingkan dengan orang lain yang lebih dari kita. Situasi ini tidak mempunyai kelompok tertentu untuk jadi perbandingan. Sebab, bukan saja Kristen, tetapi semua pemeluk agama juga disarankan agar tidak berkumpul-kumpul. Di perkantoran (Bank atau kantor pelayanan pemerintah), jarak bah- 
kan telah dibatasi tidak lebih dari 1 meter. Karena itu tidak ada alasan untuk bersungut-sungut mengikuti ibadah dari rumah, sehingga menghalangi mencapai feel good setelah bertemu Allah melalui ibadah live streaming, bersama jemaat lainnya, tentu di rumah masing-masing. Ibadah dari rumah tidak mengurangi kekudusan dan kekhusyukan ibadah itu, karena Allah hadir dalam firman yang diberitakan di dalamnya. Tentu dengan terus berdoa agar virus korona jenis baru ini cepat berlalu dan rantai penularannya pun cepat terputus dari antara umat ciptaan-Nya. Dengan keyakinan penuh pada TUHAN Piper menyatakan bahwa Allah akan membasuh umat-Nya sekalipun di dalam situasi pandemik korona (Piper, 2020, p. 25). Kebenaran Allah sendiri yang akan membasuh serta menjaga. Sosok itu disebut dengan Batu Karang oleh Joh Piper.

\section{Tinjauan Fenomena Ibadah di Rumah}

Metode fenomenologi memiliki kesamaan tujuan dengan penelitian metode interpretasi, yakni kembali kepada realitasnya atau kembali kepada gejala ada (Boiliu, 2013, p. 261). Lebih jelas Boiliu menerangkan bahwa fenomenologi adalah seni membiarkan gejala berbicara sendiri. Dengan demikian peneliti dituntun untuk mengumpulkan gejala guna menarik pengajaran dari dalamnya. Pada bagian ini peneliti akan memaparkan gejala yang terjadi di lapangan melalui penyebaran angket kepada seratus orang warga gereja yang melaksanakan ibadah di rumah. Diawali dengan dua pertanyaan umum yang diajukan pada penelitian fenomenologi (Lihat Hamzah, 2020, p. 68). Dengan pendekatan kualitatif ini diharapkan kebenaran dan pengajaran yang didapat berupa keterwakilan terhadap gejala lapangan secara nasional di Indonesia, meski seturut pendapat Silaen (Silaen, 2010, p. 88) kebenaran yang dihasilkan berasal dari gejala yang bersifat personal atau dari lokal.

Angket disebar kepada responden yang dipastikan mengikuti kebaktian online, dimana 93,6\% dengan livestreaming, baik langsung ataupun tayangan dari rekaman. Sedangkan $6,4 \%$ mengadakan ibadah di rumah dengan panduan kertas acara dari gereja yang telah dibagikan sebelumnya. Dari yang mengadakan ibadah melalui kertas panduan, lebih tiga per empat bagian dengan membaca Firman Tuhan serta mendiskusikannya sesama anggota keluarga, menjadi cara menggantikan bagian khotbah. Berikut gambaran fenomena yang terjadi digambarkan dengan gambar berikut.

Pertanyaan pertama; Apakah yang Anda alami (rasakan/pikirkan/renungkan) terkait dengan fenomena ini?

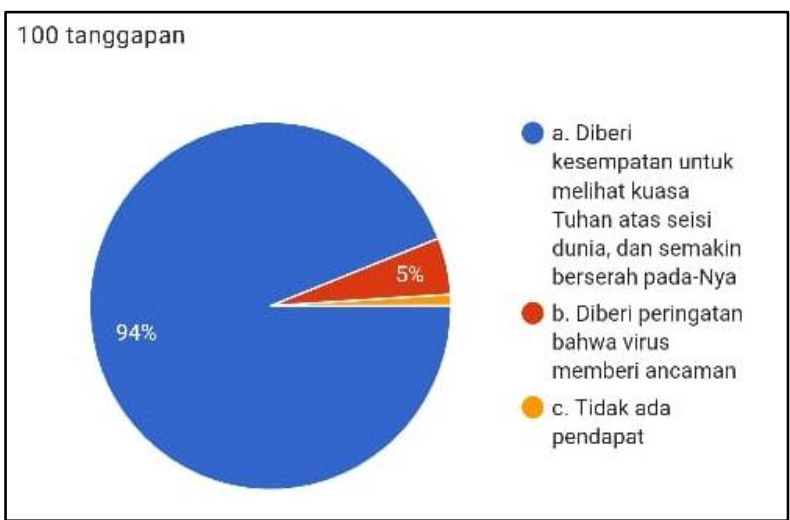

Gambar 1. Hasil Pertanyaan Pertama

Responden mengakui adanya kesempatan untuk melihat kuasa Tuhan atas seisi dunia. Dengan jumlah 94\% menunjukkan bahwa warga jemaat semakin berserah pada TUHAN dengan situasi pandemik ini. Ada juga sebagian kecil $-5 \%$, yang memaknai pandemik ini sebagai peringatan bahwa virus adalah ancaman dalam kesehatan.

Pertanyaan kedua; Apakah yang paling mempengaruhi Anda untuk menjadi serupa dengan Kristus terkait dengan fenomena ini?

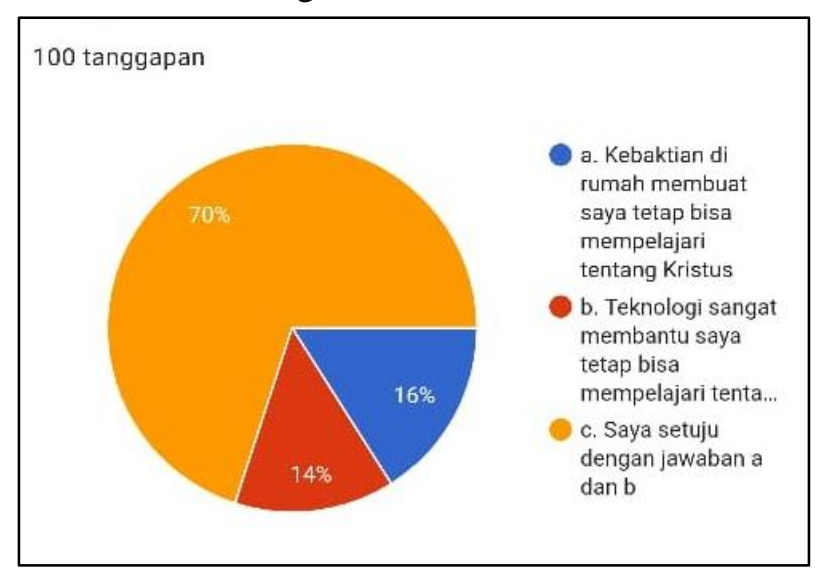

Gambar 2. Hasil Pertanyaan Kedua 
Untuk pertanyaan ini $70 \%$ responden mengakui bahwa ibadah di rumah menuntun pada pemahaman bahwa teknologi menjadi alat bantu untuk mempelajari kehendak Kristus. Karena itu situasi pandemik bukan menjadi halangan untuk tetap berdekat kepada TUHAN dengan tetap mengadakan ibadah di rumah.

Pertanyaan ketiga; Bagaimana respon Anda terhadap Firman Tuhan setiap kali setelah mengikuti ibadah di rumah, dalam segmen terhadap keluarga?

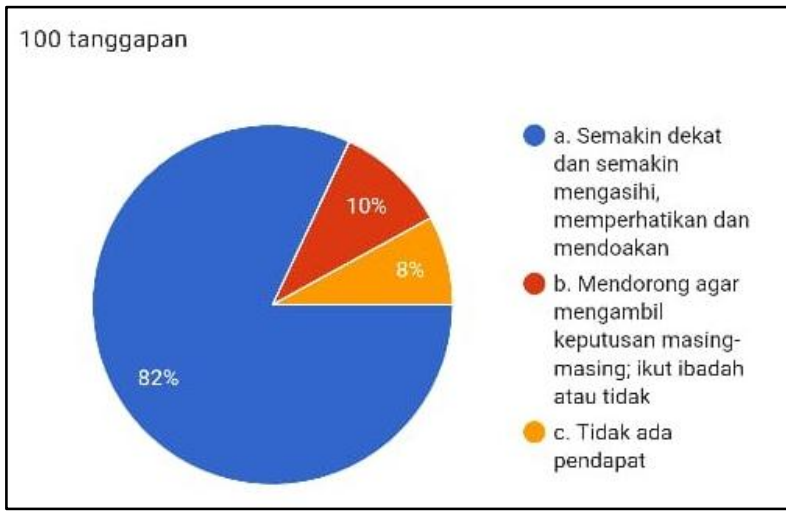

Gambar 3. Hasil Pertanyaan Ketiga

Implementasi (merespons) Firman TUHAN dalam keluarga ditunjukkan melalui memupuk kebersamaan dengan anggota keluarga di rumah, memperhatikan dan juga mendoakan (82\%). Hal ini dilakukan untuk menunjukkan rasa saling mengasihi antar anggota keluarga. Ini juga memberi gambaran kepada khalayak bahwa fenomena ibadah di rumah pada masa pandemik jadi salah satu bagian untuk menambah kehangatan dalam keluarga. Sebagian kecil responden menjawab dengan menyerahkan keputusan ikut dalam ibadah di rumah kepada masing-masing anggota keluarganya (10\%).

Pertanyaan keempat; Bagaimana respon Anda terhadap Firman Tuhan setiap kali setelah mengikuti ibadah di rumah, dalam segmen terhadap gereja (dan pelayanan terhadap jemaat)?

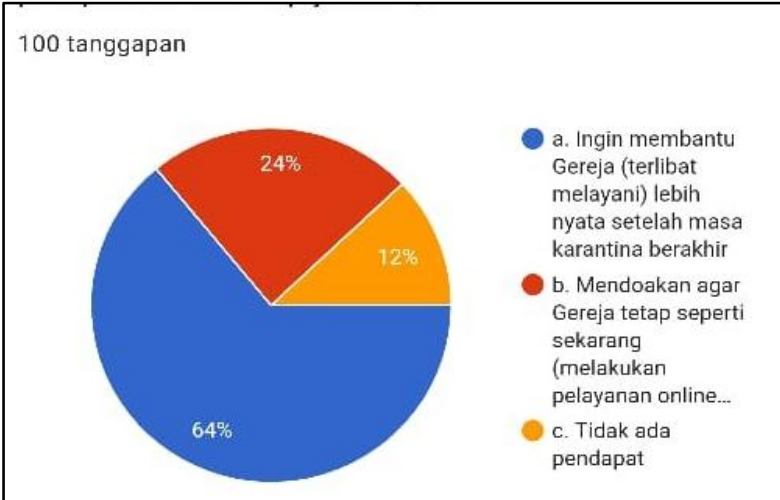

Gambar 4. Hasil Pertanyaan Keempat

Pada bagian ini jawaban responden beragam. Sebanyak $24 \%$ berharap agar gereja tetap mengadakan ibadah online/live streaming meskipun nantinya masa pandemik covid-19 telah berlalu. Ini menunjukkan keterkaitan dengan penelusuran pustaka di atas bahwa dunia digital, pelayanan di bagian daring tidak bisa dihindari lagi pada masa tehnologi informasi. Seperempat anggota jemaat mengharapkan agar Gereja mengembangkan pelayanannya menyentuh bidang daring, misalnya membangun kanal-kanal media sosial sebagai bagian pelayanan gereja yang terintegrasi. Sebanyak $64 \%$ responden menyatakan ingin terlibat dalam pelayanan gereja dengan aktif jika masa pandemik berlalu. Tampak disini ada banyak 'cadangan SDM' yang siap untuk bergabung dalam pelayanan praksis di gereja ketika beribadah di gereja dimulai saat pandemik berlalu.

Pertanyaan kelima; Bagaimana respon Anda terhadap Firman Tuhan setiap kali setelah mengikuti ibadah di rumah, dalam segmen terhadap bangsa dan negara?

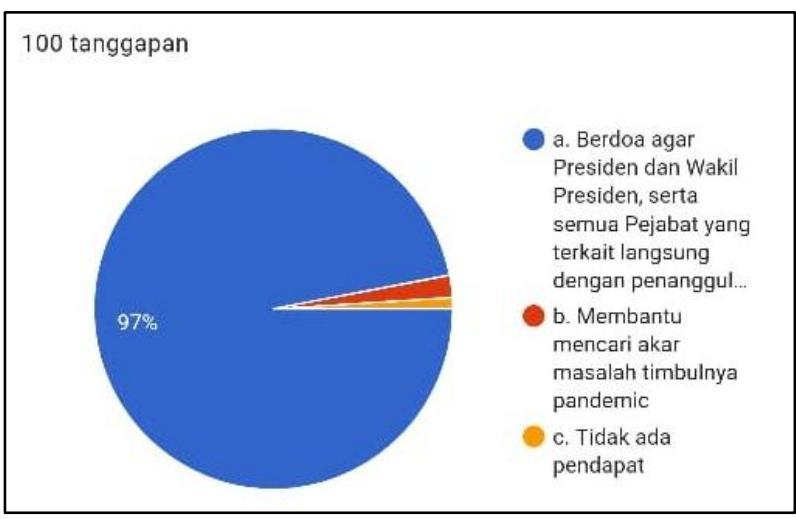

Gambar 5. Hasil Pertanyaan Kelima 
Pada bagian ini 97\% responden menyatakan mendoakan Presiden, Wakil Presiden dan semua pejabat yang terkait langsung dalam penanganan covid19 agar dituntun oleh Roh Kudus. Kepedulian kepada bangsa dan Negara adalah pesan Firman Tuhan kepada orang Kristen. Berbagai cara dapat dilakukan, salah satunya adanya mendukung dalam doa. Dengan tindakan seperti ini memberikan gambaran bahwa jemaat (melalui responden) mempunyai spiritualitas yang nyata dengan kepedulian kepada $\mathrm{Ne}$ gara di tengah pandemik covid-19. Seperti kajian pustaka di atas menyebutkan bahwa perjalanan kehiduapan rohani seseorang bisa berbeda-beda seturut konteks dan kapabilitas masing-masing.

Pertanyaan keenam; Bagaimana respon Anda terhadap Firman Tuhan setiap kali setelah mengikuti ibadah di rumah, dalam segmen terhadap lingkungan?

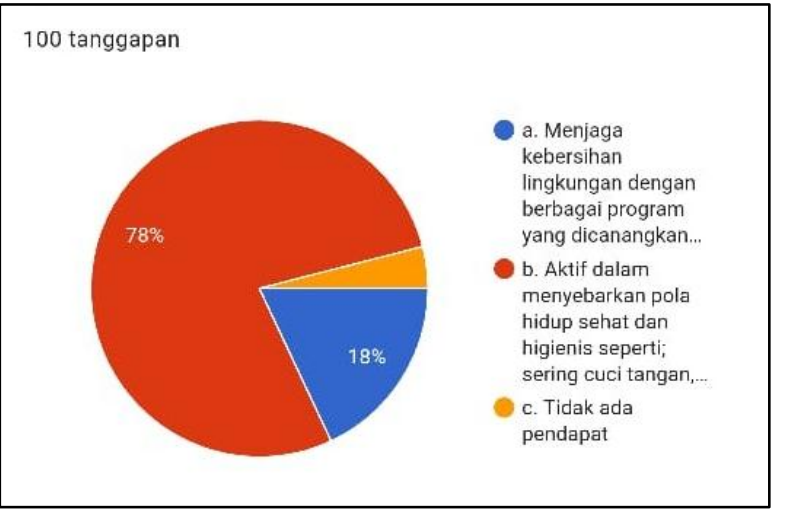

Gambar 6. Hasil Pertanyaan Keenam

Umumnya responden turut dalam upaya menyebarkan pola hidup sehat sebagai implementasi (respons) terhadap firman yang didengar dari ibadah di rumah. Sebanyak $78 \%$ responden dengan berbagai cara menebarkan anjuran agar orang-orang sering mencuci tangan, memakai masker jika harus keluar rumah, menjaga jarak dari kerumunan massa dan tidak keluar rumah adalah pilihan yang terbaik saat ini. Aktifitas seperti ini menjadi respons yang didasarkan dari pemberitaan Firman Tuhan. Sedang 18\% responden turut dalam upaya memutus rantai penularan covid-19 melalui program di lingkungan tempat tinggal dan atau tempat bekerja. Persentasi ini memberi gambaran bahwa kesadaran jemaat terhadap kesehatan masih dalam tatanan yang menggembirakan.

\section{Hasil Wawancara}

Wawancara dilakukan kepada lima orang dari dua gereja yang memiliki pengalaman beribadah di rumah selama pandemi. Wawancara dimaksud untuk mencari informasi lebih dalam atas pengalaman ibadah di rumah. Dengan pertanyaan pertama apa yang Anda alami terkait pengalaman mengikuti ibadah di rumah? Kedua hal-hal apa yang mempengaruhi kerohanian (spiritualitas) anda selama ibadah di rumah? Ketiga, bagaimana pengenalan anda akan Tuhan setelah mengikuti ibadah di rumah selama ini? Keempat apa harapan anda terhadap gereja tentang pelayanan live streaming ini ke depannya? Kelima bagaimana respons iman Anda terhadap pemerintah dengan adanya penetapan pandemi korona tersebut?

Berikut ini gambaran jawaban partisipan setelah reduksi data, dalam tabel $\mathrm{P}$ adalah partisipan.

\begin{tabular}{|l|l|l|}
\hline & \multicolumn{1}{|c|}{ Jawaban } & \multicolumn{1}{c|}{ Alasan } \\
\hline P.1 & membosankan & $\begin{array}{l}\text { Tidak bertemu teman, } \\
\text { jemaat lain }\end{array}$ \\
\hline P.2 & biasa & Ibadahnya sama \\
\hline P.3 & Tetap semangat & Ibadahnya sama \\
\hline P.4 & $\begin{array}{l}\text { Tambah dekat } \\
\text { dengan keluarga }\end{array}$ & $\begin{array}{l}\text { Lebih banyak waktu } \\
\text { bersama }\end{array}$ \\
\hline P.5 & Tetap semangat & Memuji Allah juga \\
\hline
\end{tabular}

Tabel.1 Yang dialami selama mengikuti ibadah di rumah

\begin{tabular}{|l|l|l|}
\hline & \multicolumn{1}{|c|}{ Jawaban } & \multicolumn{1}{|c|}{ Alasan } \\
\hline P.1 & Doa bersama keluarga & $\begin{array}{l}\text { Membuat makin } \\
\text { dekat }\end{array}$ \\
\hline P.2 & $\begin{array}{l}\text { Bersama keluarga me- } \\
\text { muji TUHAN }\end{array}$ & $\begin{array}{l}\text { Membuat makin } \\
\text { dekat }\end{array}$ \\
\hline P.3 & $\begin{array}{l}\text { Mendapat kesempatan } \\
\text { pelayanan seperti doa } \\
\text { pembukaan atau syafa- } \\
\text { at atau membaca warta }\end{array}$ & $\begin{array}{l}\text { Membuat anggota } \\
\text { keluarga makin } \\
\text { dekat }\end{array}$ \\
\hline P.4 & $\begin{array}{l}\text { Diskusi Firman TU- } \\
\text { HAN dengan keluarga }\end{array}$ & $\begin{array}{l}\text { Merasa TUHAN } \\
\text { hadir lebih dekat }\end{array}$ \\
\hline P.5 & $\begin{array}{l}\text { Bisa mendalami Alki- } \\
\text { tab (PA) dgn keluarga }\end{array}$ & $\begin{array}{l}\text { Merasa TUHAN } \\
\text { hadir lebih dekat }\end{array}$ \\
\hline
\end{tabular}


Tabel.2 Yang mempengaruhi kerohanian (spiritualitas) selama ibadah di rumah

\begin{tabular}{|l|l|l|}
\hline & Jawaban & \multicolumn{1}{|c|}{ Alasan } \\
\hline P.1 & $\begin{array}{l}\text { Makin } \\
\text { bertumbuh }\end{array}$ & $\begin{array}{l}\text { FT didiskusikan dengan "ba- } \\
\text { hasa keluarga", mudah dipa- } \\
\text { hami }\end{array}$ \\
\hline P.2 & $\begin{array}{l}\text { Makin } \\
\text { bertumbuh }\end{array}$ & $\begin{array}{l}\text { Banyak waktu untuk mere- } \\
\text { nungkan maksud TUHAN } \\
\text { melalui pandemi }\end{array}$ \\
\hline P.3 & $\begin{array}{l}\text { Makin } \\
\text { bertumbuh }\end{array}$ & $\begin{array}{l}\text { Yakin TUHAN hadir dalam } \\
\text { ibadh di rumah }\end{array}$ \\
\hline P.4 & $\begin{array}{l}\text { Makin } \\
\text { bertumbuh }\end{array}$ & $\begin{array}{l}\text { Yakin TUHAN hadir dalam } \\
\text { ibadah di rumah }\end{array}$ \\
\hline P.5 & $\begin{array}{l}\text { Makin } \\
\text { bertumbuh }\end{array}$ & $\begin{array}{l}\text { Tuhan menyapa umat-Nya } \\
\text { dengan corona agar lebih } \\
\text { dekat lagi }\end{array}$ \\
\hline
\end{tabular}

Tabel.3 Pengenalan akan Tuhan setelah mengikuti ibadah di rumah

\begin{tabular}{|l|l|l|}
\hline & \multicolumn{1}{|c|}{ Jawaban } & \multicolumn{1}{|c|}{ Alasan } \\
\hline P.1 & $\begin{array}{l}\text { Perlu pelayanan bi- } \\
\text { dang live } \\
\text { streaming/digital }\end{array}$ & $\begin{array}{l}\text { Pelayanan live } \\
\text { streaming/ digital bisa } \\
\text { diulang-ulang }\end{array}$ \\
\hline P.2 & $\begin{array}{l}\text { Perlu pelayanan } \\
\text { bidang live } \\
\text { streaming/digital }\end{array}$ & $\begin{array}{l}\text { Menyentuh banyak } \\
\text { kalangan; muda dan } \\
\text { orang yang malas ke } \\
\text { gereja }\end{array}$ \\
\hline P.3 & $\begin{array}{l}\text { Perlu pelayanan } \\
\text { bidang live } \\
\text { streaming/digital }\end{array}$ & $\begin{array}{l}\text { Menyentuh banyak } \\
\text { kalangan; muda dan } \\
\text { orang yg malas ke } \\
\text { gereja }\end{array}$ \\
\hline P.4 & $\begin{array}{l}\text { Kreatifitas agar } \\
\text { berlanjut dan } \\
\text { ditingkatkan }\end{array}$ & $\begin{array}{l}\text { Menyentuh banyak } \\
\text { kalangan; muda dan } \\
\text { orang yg malas ke } \\
\text { gereja }\end{array}$ \\
\hline P.5 & $\begin{array}{l}\text { Agar ada bidang } \\
\text { khusus pelayanan } \\
\text { daring di gereja }\end{array}$ & $\begin{array}{l}\text { Zaman terus berubah } \\
\text { maka gereja harus } \\
\text { turut menyinari } \\
\text { melaluinya }\end{array}$ \\
\hline
\end{tabular}

Tabel.4 Harapan terhadap gereja tentang pelayanan live streaming ke depannya

\begin{tabular}{|c|c|c|}
\hline & Jawaban & Alasan \\
\hline P.1 & $\begin{array}{ll}\text { Mendoakan } & \text { peme- } \\
\text { rintah dan } & \text { Gugus } \\
\text { Tugas C-19 } & \end{array}$ & $\begin{array}{l}\text { Pemerintah perlu } \\
\text { didukung dalam doa }\end{array}$ \\
\hline P.2 & $\begin{array}{l}\text { Mengikuti anjuran } \\
\text { wfh., sering cuci } \\
\text { tangan, pakai mas- } \\
\text { ker dan jaga jarak }\end{array}$ & $\begin{array}{l}\text { Kebersihan seba-gian } \\
\text { dari iman; pemerintah } \\
\text { adalah Hamba Allah }\end{array}$ \\
\hline P.3 & $\begin{array}{l}\text { Mengikuti anjuran } \\
\text { wfh., sering cuci } \\
\text { tangan, pakai mas- } \\
\text { ker dan jaga jarak }\end{array}$ & $\begin{array}{l}\text { Pemerintah adalah } \\
\text { Hamba Allah kare-na } \\
\text { itu warga harus patuh }\end{array}$ \\
\hline P.4 & $\begin{array}{l}\text { Mengikuti anjuran } \\
\text { wfh., sering cuci } \\
\text { tangan, pakai mas- } \\
\text { ker dan jaga jarak }\end{array}$ & $\begin{array}{ll}\text { Patuh kepada } & \text { ajuran } \\
\text { pemerintah } & \text { wujud } \\
\text { iman kristen } & \end{array}$ \\
\hline P.5 & $\begin{array}{ll}\text { Mendoakan } & \text { peme- } \\
\text { rintah dan } & \text { Gugus } \\
\text { Tugas C-19 } & \end{array}$ & $\begin{array}{l}\text { Mendoakan dan pa- } \\
\text { tuh pada pemerin-tah } \\
\text { wujud iman Kristen }\end{array}$ \\
\hline
\end{tabular}

Tabel.5 Respons iman Anda terhadap pemerintah dengan adanya penetapan pandemi korona

\section{Analisa dan Interpretasi}

Data di atas menunjukkan adanya pemaknaan tersendiri dalam diri umat Kristen terhadap penetapan pandemi korona dalam kaitan kepada spiritualitas. Pengakuan berserah diri yang besar menunjukkan satu cara Tuhan mengubah arah penyerahan diri dan kehidupan umat melalui peristiwa ini. Dalam pada itu Allah telah menyediakan sarana bagi manusia untuk tetap dekat kepadanya melalui media digital. Pengiriman ibadah melalui berbagai aplikasi menjadi cara untuk memudahkan umat dalam menjalin persekutuan di dalam Kristus yang selama masa pandemik ini mendapat halangan dalam beribadah (on site) di Gereja. Sejurus dengannya ternyata ibadah di rumah bukan hal baru bagi Allah dalam menerima kedatangan orang-orang secara bersamaan (komunal) di Gereja. Sebab sejak masa PL dan PB hingga pasca kenaikkan Yesus, ibadah di rumah adalah salah satu model yang tidak asing dalam sejarah peribadahan umat Allah. 
Dengan beribadah di rumah, dalam penelitian ini terlihat adanya pembaharuan hubungan (sosial) antara anggota keluarga serta kesempatan ambil bagian dalam mempersiapkan ibadah di rumah. Tidak bisa dipungkiri bahwa sekadar mempersiapkan posisi bangku di rumah dan perangkat elektronik salah satu cara memberi dukungan terhadap Kenyamanan ibadah. Dalam hal ini anggota keluarga tampak nyata terlibat dalam penatalayanan mempersiapkan ibadah, secara nyata di rumah. Fakta menarik dari fenomena ini adalah tantangan kesiapan Gereja untuk mempersiapkan ibadah dengan lebih menarik. Sebab jika disiarkan live, maka kesalahan-kesalahan langsung tampak dan dirasakan jemaat di rumah yang mengikuti. Tak hanya itu, estetika dalam menampilkan ibadah secara live juga menjadi satu sisi yang tidak bisa diabaikan begitu saja. Kealpaan dalam memperhatikan dua ekstrim ini berpotensi perpalingan jemaat ke Gereja lain, bahkan bisa mengarah ke ranah yang lebih buruk lagi dalam bidang spiritualias. Karena itu Gereja hendaknya mempersiapkan sumber daya manusia dan resourses yang terkait pada pelayanan dalam bidang digital. Karena analisis dari jawaban responden nyata bahwa kebutuhan untuk pelayanan ibadah pada segmen digital adalah fakta yang tidak dapat dibantah. Jika masa pandemi ini berlalu, ada 64\% jemaat yang siap untuk terjun dalam berbagai pelayanan di Gereja. Hartono dalam penelitiannya menyatakan bahwa gereja harus melihat media sebagai kesempatan pelayanan dan bagian untuk menjawab kebutuhan rohani (Hartono, 2018, p. 164). Peneliti melihat bidang media sebagai satu kondisi yang juga diyakini telah dipersiapkan Allah agar Gereja siap untuk masuk dalam pelayanan daring-digital karena Tuhan telah menyediakan banyak tenaga untuk terlibat di dalamnya.

Jika diperhatikan pertanyaan butir lima dan enam, jawaban memberi arti bahwa implementasi spiritual jemaat menuju arah praksis yang benar. Mendoakan pemerintah, patuh pada arahan pemerintah yang benar, sah dan sesuai kaidah kesehatan, ju- ga turut dalam penuntasan penularan virus korona dengan berbagai pola adalah praksis jemaat yang menghidupi nilai-nilai kristiani. Pola kehidupan spiritulitas seperti ini berarti iman jemaat bertumbuh ke arah pada keinginan Kristus.

\section{KESIMPULAN}

Dari hasil penelusuran fenomena di atas dapat dilihat gambaran yang ada di tengah-tengah warga jemaat dalam suasana pandemik. Meskipun situasi ini tidak memberi ruang gerak yang bebas dalam beribadah karena mobilitas dan pertemuan-pertemuan dibatasi, namun dalam kehidupan imannya tidak terganggu secara langsung. Diskontinuitas pandemik dengan spiritualitas tergambar dengan jelas. Catatan tersendiri dari fenomena ini pertama agar gereja memberi perhatian khusus kepada pelayanan bidang digital untuk menjangkau dua puluh lima dari seratus orang yang menyatakan pelayanan ibadah live streaming masih diinginkan pasca pandemik. Kedua, dengan rendah hati agar tidak lagi ada pemimpin gereja saling kritik hingga meruncing kepada penyebutan kata kantong kolekte dan rekening pribadi (Widjaja et al., 2020, p. 130). Sebab tanpa disadari selain menyadarkan spiritualitas yang tetap penting dijaga di masa pandemik ibadah di rumah bagai ziarah ke pola ibadah era patriark.

Penelitian ini hendaknya menjadi pemicu untuk penelitian lanjutan dalam bidang spiritualitas di tengah pandemik atau situasi tak lazim lainnya. Baik penyakit lainnya penyebab pandemik atau situasi tak lazim lain yang patut untuk dipertautkan dengan spiritualitas warga jemaat. Kepada responden dan pemimpin Gereja yang memberi peluang bagi pengumpulan data Tim Peneliti sampaikan terima kasih. Seturut hasil penelitian doa umat Tuhan disampaikan; kiranya warga jemaat kian bergairah dalam pelayanan praktis di gereja pasca pandemik karena kasih Kristus yang terus dicurahkan melampaui lintasan waktu. 


\section{DAFTAR RUJUKAN}

Boiliu, N. I. (2013). Penerapan Hermeneutika Fenomenologi Pada Penelitian Teologi: Diskursus Mengenai Metode Ilmiah Teologi. STULOS, 12, No 2, 245-264.

Budijanto, B. (2018). Spiritualitas Generasi Muda dan Gereja. In Budijanto (Ed.), Dinamika Spiritualitas Generasi Muda Kristen Indonesia (pp. 21-58). Bilangan Research Center.

Djadi, J. (2012). Spiritual Seorang Pelayan Tuhan. Jaffray, 10, No. 1, 110-117. https://doi.org/ http://dx.doi.org/10.25278/jj71.v10i1.66

Drane, J. (2017). Memahami Perjanjian Lama III (B. Ludji (ed.); Ketiga). Scripture Union Indonesia.

Efferin, H. (2013). Perubahan Dari Gereja Masa Lampau Menjadi Gereja Masa Depan Tanpa Menimbulkan Perpecahan. Amanat Agung2, 7, No 1., 79-92.

Ferguson, E. (2017). Backgrounds of Early Christianity (Ketiga). Gandum Mas.

Gunawan, A. W. (2017). Quantum Life Transformation. PT Gramedia Pustaka Utama.

Gunawan, E. (2013). Tinjauan terhadap Spiritualitas Taize dan Telaah atas Kemungkinan Mengadopsinya sebagai Pendorong bagi Spiritualitas Injili. VERITAS, 14, No 1, 15-36. https://doi.org/10.36421/veritas.v14i1.277

Hamzah, A. (2020). Metode Penelitian Fenomenologi. Literasi Nusantara.

Hartono, H. (2018). Mengaktualisasikan Amanat Agung Matius 28:19-20 dalam Konteks Era Digital. KURIOS (Jurnal Teologi Dan Pendidikan Agama Kristen), 4(2), 157-166. https://doi.org/https://doi.org/10.30995/kur.v $4 \mathrm{i} 2.87$

Hick, J. L., \& Biddinger, P. D. (2020). Novel Coronavirus and Old Lessons - Preparing the Health System for the Pandemic. The New England Journal of Medicine, 55, No 1, 1-3. https://doi.org/10.1056/NEJMp2005118

Hidayat, D. (2018). Gereja di Rumah: Kontekstualisasi Fungsi-Fungsi Rumah Dalam Masa
Perjanjian Baru Untuk Pekabaran Injil. VERITAS, 17 (2), 107--118.

Hinson, D. F. (2014). Sejarah Israel Pada Zaman Alkitab. BPK Gunung Mulia.

Hutahaean, H. (2016a). Menelisik Perumpamaan Dalam Injil Matius. Asteros, 3 No.1, 90-100.

Hutahaean, H. (2016b). Perjumpaan Kreatif Bagi Pertumbuhan Gereja Batak. Didaskein, 4 No.1, 64-73.

Hutahaean, H. (2016c). Lahir dan Berkembangnya Aliran-Aliran Gereja. In Gundari Ginting (Ed.), Sejarah dan Pertumbuhan Gereja (pp. 21-37). Prodi Teologi STTSU.

Ing, J. L. H. (2012). "Pada Zaman itu Tidak ada Raja di Antara Orang Israel" Dalam HakimHakim 17-21; Sebuah Tema Dasar dari Kitab Hakim-Hakim. Amanat Agung, 8(1), 1746.

Kapic, K. M. (2014). Pedoman Ringkas Berteologi. Waskita Publishing.

Laverty, S. M. (2003). Hermeneutic Phenomenology and Phenomenology: A Comparison of Historical and Methodological Considera-tions. International Journal of Qualitative Methods, 2(3), 21-35. https://doi.org/ $10.1177 / 160940690300200303$

Lincoln, Y. S. (2011). Dewan Peninjai Institusional dan Konservatisme Metodologis; Tantangan bagi dan dari Paradigma Fenomenologis. In N. K. Denzim \& Y. S. Lincoln (Eds.), Qualitative Research 1 (pp. 177-203). Pustaka Pelajar.

Messakh, B. J. (2018). Menuju Pelayanan Pastoral Yang Relevan dan Kontekstual. Theologia In Loco, I (1), 22-40.

Nugroho, F. J. (2017). Pendampingan Pastoral Holistik: Sebuah Usulan Konseptual Pembinaan Warga Gereja. Evangelikal: Jurnal Teologi Injili Dan Pembinaan Warga Jemaat, 1, No. 2, 139-154.

Nugroho, F. J. (2019). Gereja dan Kemiskinan: Diskursus Peran Gereja di Tengah 
Kemiskinan. Evangelikal: Jurnal Teologi Injili Dan Pembinaan Warga Jemaat, 3, No $1,100-113$.

Octavianus, S. (2018). Analisis Penggunaan Aplikasi "yesHeis" Dalam Penginjilan Pribadi. Evangelikal: Jurnal Teologi Injili Dan Pembinaan Warga Jemaat, 2, No. 1, 68-74.

Pailang, H. S. I. B. P. (2012). Membangun Spiritual Remaja Masa Kini Berdasarkan Amsal 22: 6. Jaffray, 10, No. 1, 59-86. https://doi.org/ http://dx.doi.org/10.25278/jj71.v10i1.63

Patilima, H. (2016). Metode Penelitian Kualitatif (Kelima). Cv. ALFABETA.

Piper, J. (2020). Coronavirus and Christ (Kristus dan Virus Corona) (V. Lengkong (ed.)). Literatur Perkantas Jawa Timur.

Pos, R. T. (2018). Gereja. In J. A. Boersema (Ed.), Berteologi Abad XXI (pp. 757-852). Literatur Perkantas.

Raco, J. (2010). Metode Penelitian Kualitatif; Jenis, Karakteristik dan Keunggulannya. PT. Grasindo.

Ronda, D. (2016). Pemimpin dan Media: Misi Pemimpin Membawa Injil Melalui Dunia Digital. Jaffray, 14, No. 2, 189-198. https://doi.org/http://dx.doi.org/10.25278/jj7 1.v14i2.210

Rowlley, HH. (2012). Ibadat Israel Kuno. BPK Gunung Mulia.

Setiawan, J. (2013). Ibadah Trinitarian: Defenisi, Implikasi dan Aplikasi. VERITAS, 14 (2), 165-198.

Silaen, V. (2010). Aspek Manusia Dalam Penelitian
Ilmu-Ilmu Sosial dan Humaniora. Lensa, 4, No.4., 67-98.

Silitonga, R. (2020). Respon Gereja Atas Pandemik Corona Virus Desease 2019 dan Ibadah di Rumah. Manna Rafflesia, 6(2), 86-111. https://doi.org/10.38091/man_raf.v6i2.125

Siringoringo, M. (2016). Pertumbuhan Gereja dari Persfektif Kitab Kisah Para Rasul. In G. Ginting (Ed.), Prosiding Sejarah dan Pertumbuhan Gereja (pp. 98-104). Prodi Teologi STT-SU.

Stott, J. R. W. (2010). The Radical Disciple. Literatur Perkantas Jawa Timur.

Sutoyo, D. (2018). Kairos Sebagai Golden Moment Orang Percaya. Epigraphe, 2, No 1, 32-49. https://doi.org/http://dx.doi.org/10.33991/epi graphe.v2i1.4

Tappert, T. G. (2016). The Book of Concord The Confessions of The Evangelical Lutheran Church. BPK Gunung Mulia.

Widjaja, F. I., Marisi, C. G., Togatorop, T. M. T., \& Hartono, H. (2020). Menstimulasi Praktik Gereja Rumah di Tengah Pandemi Covid19. Kairos, 6, No.1, 127-139. https://doi. org/https://doi.org/10.30995/kur.v6i1.166

Yuliana. (2020). Coronavirus diseases (Covid-19); Sebuah Tinjauan Literatur. Wellnes and Healthy, 2, No. 1, 187-192.

Zaluchu, S. E. (2020). Strategi Penelitian Kualitatif dan Kuantitatif Di Dalam Penelitian Agama. Evangelikal: Jurnal Teologi Injili Dan Pembinaan Warga Jemaat, 4(1), 28-38. https://doi.org/10.46445/ejti.v4i1.167 